Proc. Indian Acad. Sci. (Anim. Sci.), Vol. 99, No. 5, September 1990, pp. 401-409.

(C) Printed in India.

\title{
Protein requirement of juvenile Penaeus indicus. 1. Food consumption and growth
}

\section{GOPAL* and R PAUL RAJ**}

Central Marine Fisheries Research Institute, Cochin 682 031, India

*Present address: Central Institute of Brackishwater Aquaculture, 12 Leith Castle Street, Santhome, Madras 600 028, India

**Madras Research Centre of Central Marine Fisheries Research Institute, 141 Marshall's Road, Madras 600 008, India

MS received 21 April 1990; revised 22 June 1990

\begin{abstract}
Juveniles of Penaeus indicus were fed with different concentrations of protein diet $(0-60 \%$ of dry weight of diet) with purified lipid free casein as protein source. During the experimental period of 30 days, survival was only $27 \%$ in the group fed with protein free diet. Survival $(75 \%)$ and protein efficiency ratio (3.7) were maximum at 40 and $30 \%$ protein level, respectively; specific food consumption (4-3-6.7\%) and food conversion ratio (1.3-1.4) were lowest at 30 and $40 \%$ protein level, respectively. Another experiment conducted to precisely quantify the near optimum protein requirement for maximum growth of Penaeus indicus revealed significantly higher growth and protein efficiency ratio in the groups receiving $35-37.5 \%$ protein than the other groups.
\end{abstract}

Keywords. Penaeus indicus; juvenile; protein requirement; food consumption; growth; protein efficiency.

\section{Introduction}

Th requirement of prawns has been well studied and reviewed from time to 7 number of workers (New 1976; Maguire 1980; Pandian 1989). It is known to range from $22-60 \%$ of dry weight of the diet (Shewbart et al 1972; Deshimaru and Yone 1978). The wide range of values on protein requirement is mainly due to difference in the size of the experimental prawns, physiological status and other intrinsic and extrinsic factors (Abdel Rahman et al 1979; Maguire 1980). However, available studies on post-larval or juvenile Penaeus indicus suggests that the optimum protein requirement ranges from $40-43 \%$ of dry weight of the diet (Colvin 1976; Ali 1982; Bhaskar and Ali 1984). Though indicative of near precise quantification of protein requirement of $P$. indicus, these studies were conducted by offering qualitatively none too superior diet to the post-larvae juveniles. These studies were conducted by using semi-purified or compounded diets and only limited studies are available on the protein requirement of prawns by using purified diets (Bhasker and Ali 1984). As purified diets considerably reduce extraeneous nutritional factors and allow precise quantification of any particular nutrient requirement (D'Abramo et al 1982), more information is required on the protein two equirement of prawns by using purified diets. In the present study, the following two experiments were conducted on the juveniles of $P$. indicus by using casein (lipid free, which is the only protein source available in highly purified state: (i) the effect of different protein levels ( $0-60 \%$ of dry weight of diet) on growth and food using test diets (ii) near optimal quantification of protein in the juveniles by 


\section{Materials and methods}

\subsection{Experimental animals}

Juveniles of $P$. indicus belonging to the same brood stock were transported from Narrakal Prawn Hatchery of CMFRI, Cochin to the laboratory. The post-larvae were reared under laboratory conditions for 15-20 days and fed with compounded diets until they reached the required size (length: $20 \pm 5 \mathrm{~mm}$; live weight: $20 \pm 8 \mathrm{mg}$ ). Healthy juveniles of uniform size were blotted in the folds of filter paper, weighed to the nearest $\mathrm{mg}$ and transferred to the experimental aquaria. In each aquarium, 20 juveniles were reared and each treatment had 3 replicates. Prior to the commencement of the experiment, the experimental animals were starved for $24 \mathrm{~h}$ and allowed to recover from handling stress. To determine the initial dry weight, a few prawns were initially weighed and sacrificed by immersing in boiling water for a brief period (Clifford and Bricks 1983) and left for drying at $40^{\circ} \mathrm{C}$ for $48 \mathrm{~h}$ in an oven. The dried samples were reweighed. Similar procedure was adopted at the end of the experiment to determine the final dry weight of the prawns. Growth of the prawns was calculated and represented as percentage increase on wet or dry weight basis.

\subsection{Experimental aquaria}

The experiments were conducted in plastic aquaria $(54 \mathrm{~cm}$ dia.; $24 \mathrm{~cm}$ depth), mounted on vertical steel racks. In each aquarium 401 of filtered, irradiated and dilute seawater (salinity: $20 \pm 2 \cdot 5 \%$ ) (Colvin 1976) was used. The water was continuously aerated and was replaced on alternate days.

\subsection{Test diets}

Isocalorically adjusted graded levels of protein test diets from $0-60 \%$ with an interval of $10 \%$ protein for the first experiment and from $32 \cdot 5-47 \cdot 5 \%$ with an interval of $2.5 \%$ protein for the second experiment were formulated following earlier studies (Kanazawa et al 1970, 1977; Adelung and Ponat 1977; Conklin et al 1978). Finely powdered, preweighed ingredients except cellulose, starch, lipids (oils) and vitamins were mixed in Warring blender. Gelatin was dissolved in cold water and later boiled with cellulose and starch. After gelatinization, corn oil and cod-liver oil containing fat soluble vitamins were added and heated in water bath for $10 \mathrm{~min}$. The ingredients were mixed thoroughly and then steamed at $115 \mathrm{lb}$ pressure for $5 \mathrm{~min}$. The steamed feed was allowed to cool to room temperature and then the vitamin mixture was added and mixed thoroughly. The $\mathrm{pH}$ of the diet was adjusted to 6.8 (Kanazawa et al 1977) using $0.1 \mathrm{~N} \mathrm{NaOH}$ and the feed was stored in polyethylene bags in a freezer. The moisture content in the feed was adjusted to $30 \%$. Before feeding the prawns, the feed was thawed to room temperature and made into small balls and weighed. The protein content in the diets werc accordingly adjusted without changing the calorie content. The composition of the formulated diets for each experiment is as shown in table 1. 
Table 1. Composition of experimental diets.

\begin{tabular}{|c|c|c|c|c|c|c|c|c|c|c|c|c|c|c|}
\hline \multirow{2}{*}{$\begin{array}{l}\text { Ingredient } \\
\mathrm{g} / 100 \mathrm{~g}\end{array}$} & \multicolumn{7}{|c|}{ Experiment 1} & \multicolumn{7}{|c|}{ Experiment 2} \\
\hline & 0 & 10 & 20 & 30 & 40 & 50 & 60 & $32 \cdot 5$ & 35 & $37 \cdot 5$ & 40 & $42 \cdot 5$ & 45 & $47 \cdot 5$ \\
\hline Casein (lipid-free) & - & 11 & 21 & 31 & 41 & 51 & 61 & 34 & 36 & 39 & 41 & 44 & 46 & 49 \\
\hline Egg albumin & - & 1 & 1 & 1 & 1 & 1 & 1 & 1 & 1 & 1 & 1 & 1 & 1 & 1 \\
\hline Gelatin & - & 1 & 1 & 1 & 1 & 1 & 1 & 1 & 1 & 1 & 1 & 1 & 1 & 1. \\
\hline Glucosamine-HCl & - & 1 & 1 & 1 & 1 & 1 & 1 & 1 & 1 & I & 1 & 1 & 1 & 1 \\
\hline Sucrose & $20-11$ & $19 \cdot 9$ & $15 \cdot 43$ & 11.68 & $7 \cdot 24$ & $4 \cdot 68$ & $1 \cdot 18$ & $10 \cdot 25$ & $9 \cdot 65$ & 8.28 & $7 \cdot 24$ & 6.86 & $6 \cdot 65$ & $5 \cdot 45$ \\
\hline Glucose & $10 \cdot 19$ & $7 \cdot 19$ & 6.53 & $4-96$ & $3 \cdot 68$ & $2 \cdot 32$ & $0-9$ & $4 \cdot 61$ & $4 \cdot 41$ & $4 \cdot 20$ & 3.68 & $3 \cdot 33$ & 2.75 & $2 \cdot 5$ \\
\hline Starch & $43 \cdot 45$ & $32 \cdot 59$ & $27 \cdot 39$ & $22 \cdot 61$ & $18 \cdot 51$ & $12 \cdot 98$ & 7.65 & $21 \cdot 65$ & $20 \cdot 58$ & $18 \cdot 89$ & $18 \cdot 51$ & $15 \cdot 61$ & 14.92 & 13.66 \\
\hline Cod-liver oil & 6 & 6 & 6 & 6 & 6 & 6 & 6 & 6 & 6 & 6 & 6 & 6 & 6 & 6 \\
\hline Corn oil & 3 & 3 & 3 & 3 & 3 & 3 & 3 & 3 & 3 & 3 & 3 & 3 & 3 & 3 \\
\hline Cholesterol & 0.5 & $0-5$ & 0.5 & $0-5$ & 0.5 & $0-5$ & 0.5 & 0.5 & 0.5 & 0.5 & 0.5 & 0.5 & 0.5 & 0.5 \\
\hline Sodium succinate & 0.3 & 0.3 & 0.3 & $0-3$ & $0 \cdot 3$ & 0.3 & 0.3 & 0.3 & $0-3$ & $0 \cdot 3$ & 0.3 & $0 \cdot 3$ & 0.3 & 03 \\
\hline Sodium citrate & 0.3 & 03 & 0.3 & 0.3 & 0.3 & 0.3 & 0.3 & $0-3$ & 03 & 0.3 & $0 \cdot 3$ & 0.3 & 03 & $0-3$ \\
\hline Mineral mixture* & $7 \cdot 41$ & $7 \cdot 41$ & $7 \cdot 41$ & $7 \cdot 41$ & $7 \cdot 41$ & $7 \cdot 41$ & $7 \cdot 41$ & 7.41 & $7 \cdot 41$ & 7.41 & $7 \cdot 41$ & $7 \cdot 41$ & $7-41$ & $7 \cdot 41$ \\
\hline Vitamin mixture** & $3 \cdot 24$ & $3 \cdot 24$ & $3 \cdot 24$ & $3 \cdot 24$ & 3.24 & $3 \cdot 24$ & $3 \cdot 24$ & $3 \cdot 24$ & $3-24$ & $3 \cdot 24$ & $3 \cdot 24$ & $3 \cdot 24$ & $3 \cdot 24$ & $3 \cdot 24$ \\
\hline Agar-agar & 2 & 2 & 2 & 2 & 2 & 2 & 2 & 2 & 2 & 2 & 2 & 2 & 2 & 2 \\
\hline Cellulose & 4 & 4 & 4 & 4 & 4 & 4 & 4 & 4 & 4 & 4 & 4 & 4 & 4 & 4 \\
\hline
\end{tabular}

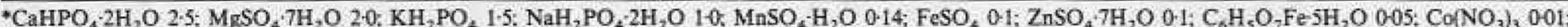
$\mathrm{CuSO}_{4} \cdot 5 \mathrm{H}_{2} \mathrm{O}, 001$.

**-Carotene 0-014; calciferol 0002; $\alpha$-tocopherol acetate 0-032; menadione 0.032; ascorbic acid 2.424; thiamine hydrochloride 0.01; riboflavin 0-008; nicotinic acid 0.032; pyridoxine hydrochloride 0.016 ; calcium pantothenate 0.06 ; folic acid 0.001 ; p-aminobenzoic acid 0.014 ; choline chloride $0-3$; inositol 0.3 ; biotin $0-004$; cyanocobalamin 0001 


\subsection{Estimation of food consumption}

The prawns were fed with the test diets twice a day at the rate of $10 \%$ (dry weight feed) of live body weight/day. The uneaten food was collected every day by siphoning the water through bolting silk; the residue was washed in distilled water to remove the adhering salts and transferred to preweighed aluminium foils, dried and weighed at $70^{\circ} \mathrm{C}$ for $48 \mathrm{~h}$. The total dry feed consumed by the prawns in each group was determined every day by subtracting the dry weight of uneaten food from the dry weight of food offered. Specific food consumption (SFC) (Bordner and Conklin 1981; Gopal 1986), food conversion ratio (FCR) and protein efficiency ratio (PER) were calculated as follows:

$$
\begin{gathered}
\text { Total initial dry wt. of food } \\
\text { offered }
\end{gathered}
$$

SFC $(\%)=\frac{\begin{array}{c}\text { Number of animals } \\ \text { surviving at the end of } \\ \text { experiment }\end{array}}{0} \times 100$

Total dry wt. of - Total dry wt. of food offered uneaten food
FCR $=\frac{\text { Final wet wt. of }+ \text { Wet wt. of dead }- \text { Initial wet wt. of }}{\text { ping }}$ prawns prawns prawns

Final wet wt. of prawns - Initial wet wt. of prawns

$$
\mathrm{PER}=\frac{\text { Total protein intake }}{\text { Thal }}
$$

For each of these parameters, the mean values of the replicates per treatment was considered for the statistical calculation.

\subsection{Experimental conditions}

The mean water temperature, $\mathrm{pH}$ and ammonia levels in the aquaria for both experiments were $27 \cdot 7 \pm 1 \cdot 9 / 27.6 \pm 2.27^{\circ} \mathrm{C} ; 8.4 \pm 1.0 / 8.02 \pm 0.5$ and $0.04 \pm 0.01$ / $0.02 \pm 0.003 \mathrm{NH}_{4}-\mathrm{N} \mathrm{mg} / \mathrm{l} /$ day, respectively. Samples of each diet were analysed for crude protein, lipids and moisture following the methods suggested by AOAC (1975). Water samples were analysed using standard methods (Strickland and Parsons 1972; Spotte 1979).

\subsection{Statistical analysis}

All the parameters (SFC, FCR, PER) estimated are apparent and no correction factor was introduced for the exuviae and dead prawns eaten by the cohabitors during the experimental study. The data collected were statistically analysed using the test of significance and variance (ANOVA) and the means of the treatments were compared by the least significance difference method (LSD) (Snedecor and Cochran 1973). 


\section{Results and discussion}

\subsection{Survival}

The protein concentration in the diet significantly $(P<0.05)$ influenced the survival of $P$. indicus. During the experimental study of 30 days, only $27 \%$ of prawns receiving $0 \%$ protein level survived and the percentage of survival was $75 \%$ in the group receiving $40 \%$ protein (figure 1). As more than $50 \%$ of prawns survived at $10 \%$ protein level, $10 \%$ protein in the diet may be considered as the critical protein level for the survival of the juveniles. Beyond $40 \%$ protein, the survival rate declined, indicating the adverse effect of excess dietary protein on the prawns. Weekly survival rate at different protein levels shows that the mortality of prawns fed with protein free diet was higher from the second week onwards. It was observed that most of the prawns receiving protein free diet succumbed immediately after molting. They were also not active and the cohabitors resorted to cannibalism. Cannibalism was evident in all the groups, more so in the groups receiving excess protein $(>40 \%)$.

\subsection{Specific food consumption}

The SFC of $P$. indicus was influenced by the protein content in the diet. It was $33.7 \%$ for the groups receiving protein free diet as against amongst the groups receiving $10-60 \%$ protein, it was minimum $(4.3 \%)$ at $40 \%$ protein (figure 2 ). Thus, prawns fed on protein free diet consumed 8 times more than the juveniles fed with protein in the diet. Inspite of the fact that the prawns fed with protein free diet consumed more than the other prawns, even then there was large scale mortality suggesting that protein forms the basic nutrient in the diet of the prawns. Further it was observed that as the protein concentration increases, the SFC falls sharply up to $40 \%$ protein level. Thus, it appears that juveniles of prawns when exposed to

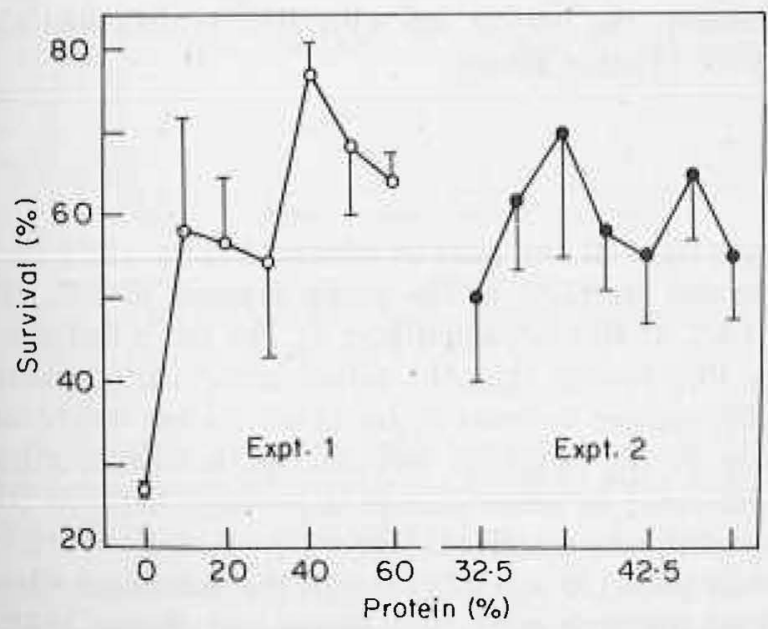

Figure 1. Per cent survival of juvenile $P$. indicus fed with different levels of protein in the diet $(0-60 \% / 32 \cdot 5-47 \cdot 5 \%)$. 


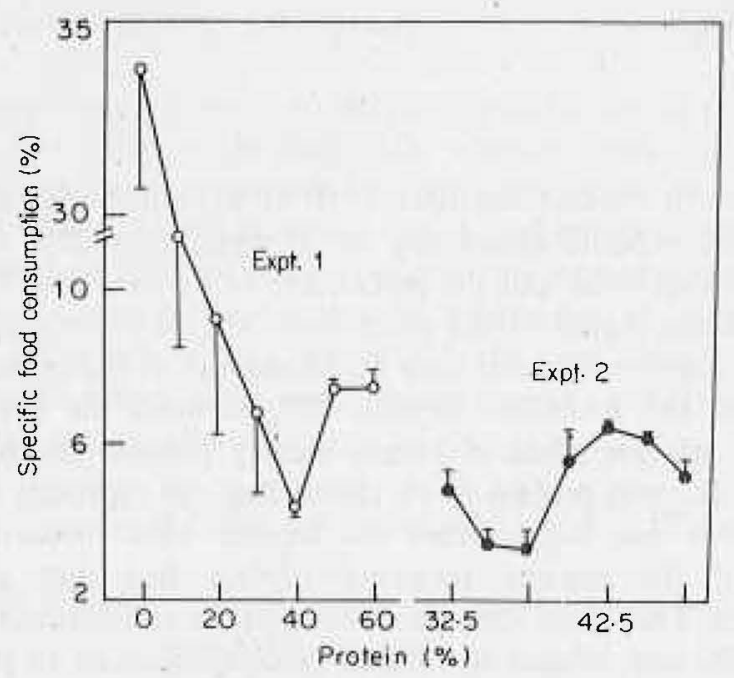

Figure 2. Specific food consumption in juvenile $P$. indicus fed with different levels of protein in the diet $(0-60 \% / 32 \cdot 5-47 \cdot 5 \%)$.

optimum level do not load the stomach with excess energy but prefer to consume required quantum of protein based energy. However, exposure to very high protein levels $(50$ and $60 \%$ ) induces the prawns to increase the food consumption, thereby loading the stomach with very high protein energy.

\subsection{FCR and PER}

The FCR and PER (figure 3) were also significantly influenced by the protein content in the diet. The FCR sharply declined from $4.6 \pm 0.4$ in the prawns fed with protein-free diet to $1.3 \pm 0.9$ at $30 \%$ protein; these values were statistically significant $(t=16.9 ; P<0.05)$. Similarly, the prawns fed with $30 \%$ protein had significantly higher PER than the PER of other groups.

\subsection{Growth}

The mean gain in dry weight of the prawns increased from $125 \%$ in the group exposed to protein-free diet to $522 \%$ in the group exposed to $40 \%$ protein and thereafter declined to $430 \%$ at $60 \%$ protein (figure 4). The sharp increase in growth of the group receiving $30 \%$ protein than the earlier group (20\% protein) and the maximum growth at $40 \%$ protein in terms of dry as well as wet weight suggest that $30-40 \%$ of protein may be the optimum level for the maximum growth of the juvenile prawn. The difference in mean gain in dry weight between 30 and $40 \%$ protein levels was not statistically significant (dry wt.; $t=0.25, P>0.05$ ). The decline in growth at high protein levels $(50$ and $60 \%$ ) reveals the deleterious effect of excess protein in the diet (Venkatramiah et al 1975; Bages and Sloane 1981; Vernberg 1987). Thus, it was observed that when juvenile prawns are fed with optimum protein diets, the growth and protein efficiency tends to be maximum and the 


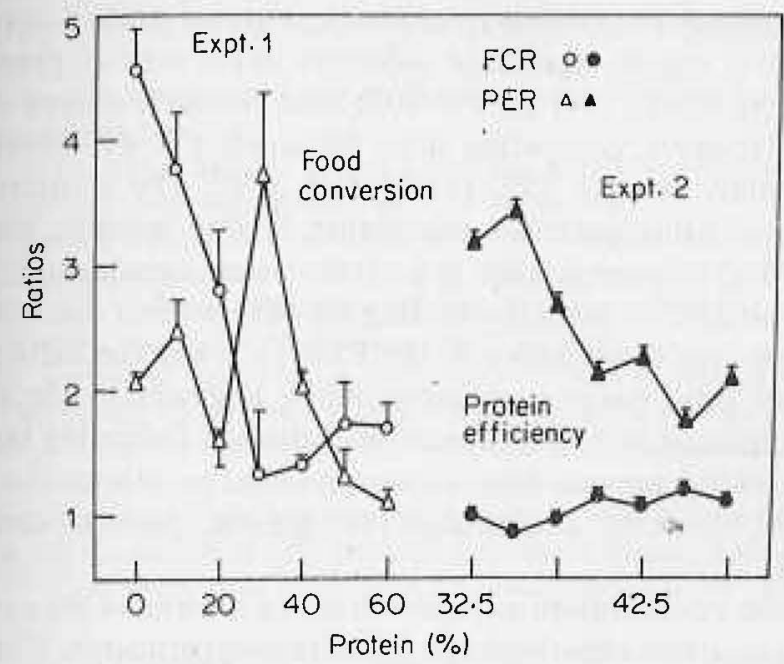

Figure 3. Food conversion ratio and protein efficiency ratio in juvenile $P$. indicus fed with different levels of protein in the diet $(0-60 \% / 32 \cdot 5-47 \cdot 5 \%)$.

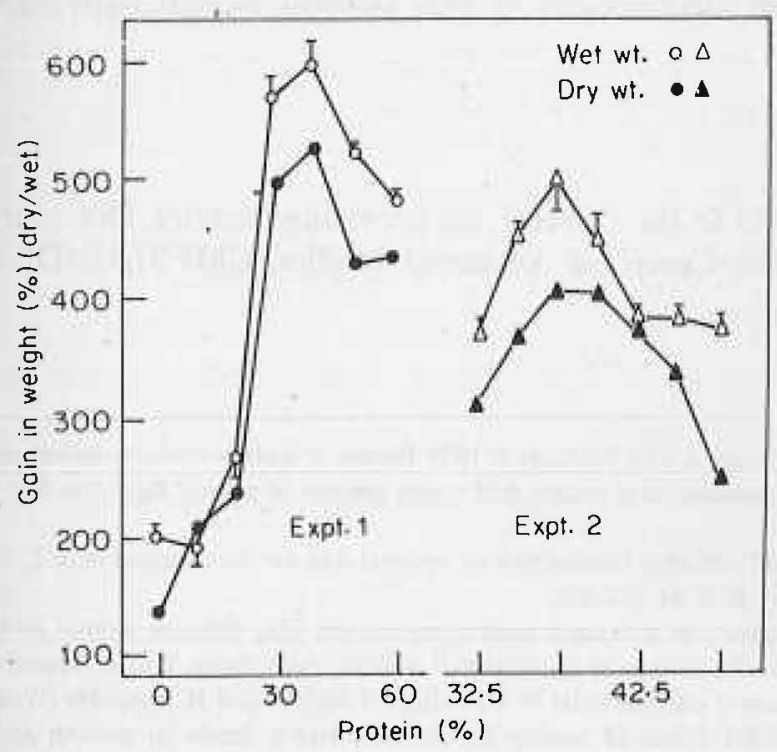

Figure 4. Per cent gain in weight by juvenile $P$. indicus fed with different levels of protein in the diet $(0-60 \% / 32 \cdot 5-47 \cdot 5 \%)$.

specific food consumption and food conversion ratio are the lowest thereby suggesting the importance of protein based energy diets which are efficiently utilized by the animals.

\subsection{Near optimal protein requirement}

The second experiment on the juveniles of $P$. indicus was conducted based on the 
results of the first experiment to precisely quantify the optimal protein requirement. It was observed that there was no significant difference in the survival percentage in the test groups $(32.5 \%$ vs $47.5 \% ; t=1.35 ; P>0.05)$ since the diets offered were near optimal requirement. However, comparing other parameters it was observed that the SFC was significantly low at $35 \%(3.4 \%)$ and $37.5 \%(3.3 \%)$ protein levels compared to the SFC of other protein levels (figure 2). For instance, the SFC of juveniles feeding on $37.5 \%$ protein diet $(3.3 \pm 0.6 \%)$ was significantly $(t=20.42$; $P<0.05)$ lower than the SFC of juveniles feeding on $40 \%$ protein diet $(5.6 \pm 0.7 \%)$. Similarly, the FCR $(0.8)$ was the lowest and the PER (3.5) was the highest at $35 \%$ protein level. Thus, all these parameters substantially augment to the maximum mean gain in weight obtained at $37.5 \%$ protein level thereby indicating the optimal level around 35 and $37.5 \%$ protein level (figure 4). The growth of the juveniles declined beyond $40 \%$ protein, confirming the growth pattern obtained in experiment 1 (figure 4).

A comparison of food consumption and growth of the prawns of the experiments 1 and 2 revealed a few differences between these two experiments. The growth, especially, was slower in experiments 1 and 2 . The difference may be due to genetic variations in the brood stock, as the juvenile prawns used for the experiments were from two different stocks. Nevertheless, a definite trend was obtained in experiment 2 which has facilitated identification of near optimal protein requirement of the juvenile prawns.

\section{Acknowledgements}

The authors are grateful to the Director, for providing facilities. One of the authors (CG) acknowledges the Centre of Advanced Studies, CMFRI/UNDP/ICAR for providing fellowship.

\section{References}

Abdel-Rahman S H, Kanazawa A and Teshima S 1979 Effects of dietary carbohydrates on growth and the levels on the hepatopancreatic glycogen and serum glucose of prawn; Bull. Jpn. Soc. Sci. Fish. 45 1491-1494

Adelung D and Ponat A 1977 Studies to establish an optimal diet for the decapod crab C. maenas under culture conditions; Mar. Biol. 44 287-292

Ali S A 1982 Relative efficiency of pellatized feeds compounded with different animal proteins and the effect of protein level in the growth of the prawn P. indicus; Proc. Symp. Coast. Aquacult. $1321-328$

AOAC 1975 Opictal methods of analysis (eds) W Horwitz, P Chichilo and H Reynolds (Washington DC)

Bages M and Sloane L 1981 Effect of dietary protein and starch levels on growth and survival of P. monodon post-larvae; Aquaculture 25 117-128

Bhaskar T I C J and Ali S A 1984 Studies on the protein requirement of post-larvae of the penaeid prawns $P$. indicus using purified diets; Indian $J$. Fish. 31 74-81

Bordner C E and Conklin D E 1981 Food consumption and growth of juvenile lobsters $H$. americanus; Aquaculture 24 285-300

Clifford III H C and Bricks R W 1983 Nutritional utilization in the freshwater shrimp $M$. rosenbergll I. Substrate metabolism in fasting juvenile shrimp; Comp. Biochem. Physiol. A74 561-568

Colvin P M 1976 Nutritional studies on penaeid prawns: Protein requirements in compounded diets for juvenile $P$. indicus; Aquaculture 7 315-326

Conklin D E, Goldblatt M J, Bordner C E, Baum N E and MeCormick T B 1978 Artificial diets lor lobsters H. americanus. A revaluation; Proc. Ann. Meet. World Maricult. Soc. 9 243-250

D'Abramo L R, Bordner C E and Conklin D E 1982 Relationship between dietary phosphatidyl choline and serum cholesterol in the lobster Homarus sp.: Mar. Biol. 67 231-235 